\title{
SISTEM PENGATURAN KECEPATAN MOTOR UNIVERSAL SATU FASA DENGAN METODE KONTROL SUDUT FASA BERBASIS MIKROKONTROLER AT89S52
}

\author{
I Gede Nurhayata \\ Jurusan Teknik Elektronika \\ Fakultas Teknik dan Kejuruan \\ Universitas Pendidikan Ganesha \\ email : gede_nur@yahoo.co.id
}

\begin{abstract}
Abstrak
Motor universal banyak digunakan sebagai tenaga penggerak pada peralatan listrik portable seperti gerinda, mixer, blender dimana pengaturan kecepatannya umumnya memiliki jangkah yang terbatas dan tidak halus Tujuan penelitian ini adalah mengembangkan sistem pengaturan kecepatan motor universal yang mampu memberikan jangkah pengaturan lebih lebar dan halus. Penelitian diawali dengan perancangan hardware untuk kendali thyristor dengan metode kontrol sudut fasa. Selanjutnya perancangan perangkat lunak berbasis mikrokontroler AT89S52 untuk mengatur sudut fasa penyalaan thyristor secara digital. Hasil penelitian menunjukkan bahwa mikrokontroler AT89S52 mampu menghasilkan pengaturan nilai sudut fasa penyalaan thyristor yang linier dalam rentang sudut nol derajat sampai 180 derajat namun linieritas tersebut tidak sepenuhnya menghasilkan linieritas pada pengaturan kecepatan motor universal .
\end{abstract}

Kata kunci : motor universal, mikrokontroller AT89S52

\begin{abstract}
Universal motors are widely used as a driving force in portable electrical equipment such as grinders, mixers, blenders where the speed settings generally have limited ranges and are not subtle purpose of this study is to develop a universal motor speed control system which is able to provide wider ranges and refined setting. The study begins with the design of the hardware to control thyristor phase angle control method. Furthermore, the design of softwarebased microcontroller AT89S52 to adjust the phase angle of the thyristor ignition digitally. The results showed that the AT89S52 microcontroller capable of generating the setting value of the phase angle of the thyristor ignition linear in the range of angle of 0 degrees to 180 degrees, but linearity is not fully produce the linearity of the universal motor speed control.
\end{abstract}

Keywords: universal motors, the microcontroller AT89S52 



\section{PENDAHULUAN}

Dewasa ini kebutuhan peralatan listrik yang menggunakan motor listrik sebagai tenaga penggerak meningkat demikian pesat. Keberadaan peralatan listrik tersebut telah banyak membantu meringankan sebagian besar pekerjaan manusia khususnya yang melibatkan pemakaian tenaga fisik. Motor universal merupakan salah satu jenis motor listrik sebagai tenaga penggerak yang hampir sebagian besar digunakan pada peralatan mesin industri maupun rumah tangga seperti gerinda, bor tangan, mixer, mesin jahit, blender dan lain sebagainya. Kecepatan yang tinggi dan torsi awal yang besar serta ukuran fisik yang kecil dari motor universal memberikan keunggulan lebih dibandingkan dengan jenis motor listrik yang lain.

Peralatan listrik dengan tenaga penggerak motor universal umumnya dilengkapi dengan pengaturan kecepatan yang terbatas pada beberapa pilihan level kecepatan tertentu sehingga pengaturannnya menjadi tidak halus. Pemilihan kecepatan penggerak motor universal sangat bergantung pada jenis pekerjaan dan bahan yang akan diolah. Pada suatu pekerjaan tertentu dan pengerjaan bahan yang murah biasanya menuntut waktu proses yang cepat sehingga cukup menggunakan satu level kecepatan maksimum saja. Namun pada suatu pengolahan bahan kerja yang mahal dan menuntut hasil kinerja terbaik tentu harus menggunakan kecepatan tenaga penggerak yang tepat sehingga untuk pekerjaan ini dibutuhkan tenaga penggerak motor universal yang mampu memberikan variasi kecepatan yang lebar dan halus.

Pengaturan kecepatan motor universal yang lebar dan halus hanya dapat dilakukan secara elektronik melalui pengendalian komponen thyristor. Di pasaran perangkat elektronik ini dapat ditemukan sebagai kendali intensitas lampu pijar yang biasa dinamakan dimmer. Pandangan masyarakat awam, alat tersebut dianggap dapat digunakan sebagai pengatur kecepatan motor universal sehingga hasil pengaturan kecepatannya menjadi tidak stabil khususnya pada kecepatan rendah.
Disamping itu kelemahan lainnya pada kecepatan rendah torsi motor penggerak menjadi rendah sehingga tidak mampu menggerakkan beban pada kondisi awal. Hal tersebut di atas disebabkan karena perangkat dimmer hanya dikhususkan untuk pengaturan beban resistip yang salah satunya berupa lampu pijar sedangkan motor universal bukan beban resistip melainkan beban induktif sehingga pengaturan kecepatannya jelas berbeda. Oleh karena itu, dalam penelitian ini perlu mengembangkan pengaturan kecepatan motor universal dengan pengendalian terhadap komponen thyristor menggunakan metode kontrol sudut fasa untuk memperoleh pengaturan kecepatan yang lebih lebar dan halus. Dalam penelitian ini pengontrolan sudut fasa tidak dilakukan secara analog melainkan secara digital dengan menerapkan mikrokontroler AT89S52.

Berdasarkan permasalahan di atas dalam penelitian ini dirumuskan beberapa pokok masalah yakni perancangan perangkat lunak (software) dalam pengontrolan sudut fasa penyalaan thyristor berbasis mikrokontroller AT89S52 dan linieritas hubungan antara tegangan keluaran motor universal terhadap pengaturan sudut fasa penyalaan thyristor. Tujuan dalam penelitian ini adalah mengembangkan sistem pengaturan kecepatan motor universal secara digital berbasis mikrokontroler AT89S52 sehingga diperoleh pengaturan yang lebar dan halus.

\section{KAJIAN TEORI}

Motor universal sesuai dengan namanya adalah salah satu motor listrik yang bekerja pada sumber tegangan listrik arus bolak-balik (AC) dan pada arus searah (DC) karena memiliki konstruksi yang sama dengan motor dc seri. Adapun konstruksi dari motor universal seperti tampak pada gambar 1 . 


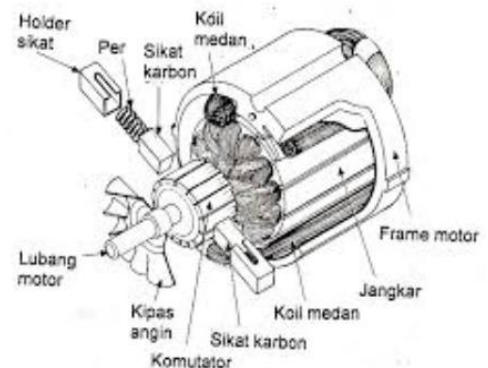

Gambar 1. Konstruksi Motor Universal

Prinsip kerja motor universal dapat dijelaskan pada gambar 2 dimana sumber tegangan bolak-balik membangkitkan medan magnet bolak-balik pada inti besi stator yang berubah arah sesuai dengan polaritas sumber tegangan. Pada kumparan rotor mengalir arus dan membangkitkan medan magnet rotor yang juga berubah sesuai dengan perubahan arah polaritas sumber. Interaksi kedua medan magnet tersebut menyebabkan timbul gaya gerak yang mengakibatkan rotor berputar.
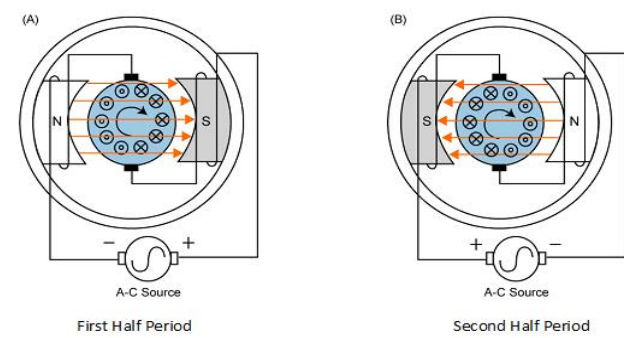

Gambar 2. Prinsip Kerja Motor Universal

Konstruksi motor universal dapat dinyatakan dalam bentuk rangkaian ekivalen seperti tampak pada gambar 3 .

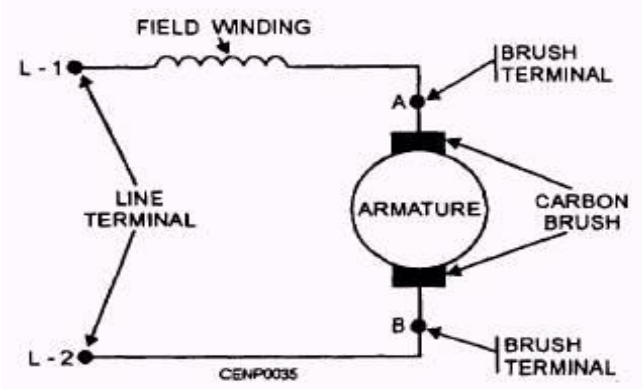

Gambar 3. Rangkaian Ekivalen Motor Universal

Berdasarkan rangkaian tersebut dapat dinyatakan persamaan tegangan sumber Vs dari motor universal sebagai berikut :

$V s=E a+I a(R s+j X s)$ sehingga kecepatan motor universal dapat dinyatakan dengan persamaan sebagai berikut :

$$
n=\frac{E a}{c . \Phi}=\frac{V s-I a(R s+j X s)}{c . \Phi}
$$

dimana :

$$
\mathrm{n} \quad=\text { kecepatan motor universal }
$$

Vs $=$ tegangan sumber

la $=$ arus jangkar

Rs = resistansi kumparan medan stator

$X s=$ reaktansi kumparan medan stator

$\Phi=$ fluks medan magnet stator

C = konstanta motor

Berdasarkan persamaan tersebut di atas maka kecepatan putaran motor universal dipengaruhi oleh besarnya tegangan sumber Vs dan arus jangkar la. Besarnya arus jangkar dipengaruhi oleh faktor pembebanan atau torsi beban sehingga jika semakin besar beban maka kecepatannya akan menurun seperti tampak pada gambar 4. Pada gambar terlihat bahwa kecepatan motor universal merosot tajam seiring dengan perubahan beban, namun pada operasi sumber arus searah (dc) memiliki kecepatan yang lebih besar dibandingkan pada sumber arus bolak-balik (ac).

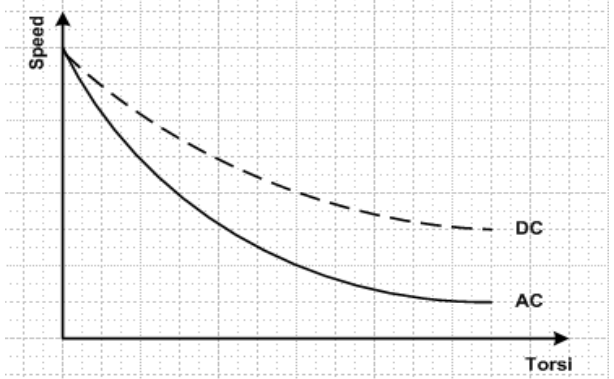

Gambar 4. Karakteristik Motor Universal

Pengaturan kecepatan motor universal dapat dilakukan dengan mengatur variabel tegangan sumber Vs. Dari persamaan kecepatan motor diatas, dapat diketahui semakin besar tegangan sumber maka kecepatan motor universal akan semakin meningkat demikian pula sebaliknya. Dengan demikian pengaturan kecepatan motor universal hanya dapat dilakukan dengan mengatur tegangan sumber yang menuju ke motor universal. 


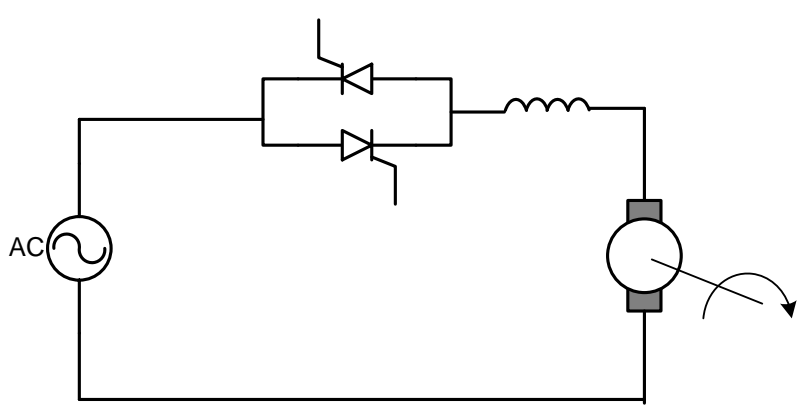

Gambar 5. Rangkaian pengatur tegangan ac dengan sudut fasa

Salah satu metode pengaturan tegangan sumber bolak-balik pada beban dapat dilakukan dengan mengatur sudut fasa penyulutan pada thyristor seperti tampak pada gambar 5. Prinsip kerjanya dimana kedua thyristor disulut secara bergantian pada tiap belahan gelombang sehingga menghasilkan bentuk tegangan keluaran pada beban seperti tampak pada gambar 6. (JM. Bourgeois dkk, 1994)

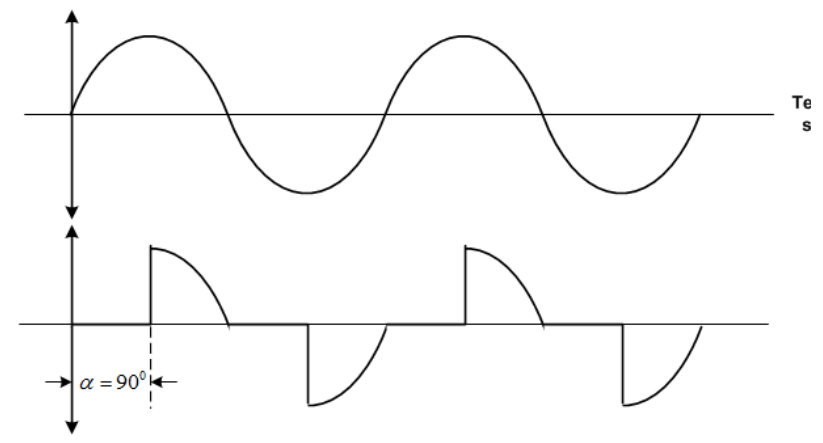

Gambar 6. Bentuk tegangan keluaran pada sudut penyulutan 90 derajat

Hubungan antara tegangan keluaran efektif dengan sudut fasa penyalaan thyristor pada beban motor universal dapat dinyatakan sebagai berikut (Robert W. Erickson, 2001) :

$$
V o=\sqrt[2]{\frac{V m^{2}}{2 \pi}\left(\pi-\alpha+\frac{1}{2} \sin 2 \alpha\right)}
$$

dimana :

$$
\begin{aligned}
& \mathrm{Vo}=\text { tegangan keluaran efektif } \\
& \mathrm{Vm}=\text { tegangan maksimum sumber } \\
& \alpha \quad=\text { sudut fasa penyalaan }
\end{aligned}
$$

dari persamaan di atas dapat diketahui bahwa semakin besar sudut penyalaan thyristor maka semakin kecil tegangan keluaran efektifnya. sistem mikrokontroler adalah sebuah terkandung didalam sebuah chip yang mempunyai masukan dan keluaran serta kendali dengan program yang bisa ditulis dan dihapus dengan cara yang khusus. Dalam penelitian ini menggunakan mikrokontroler tipe AT89S52 seperti tampak pada gambar 7 .

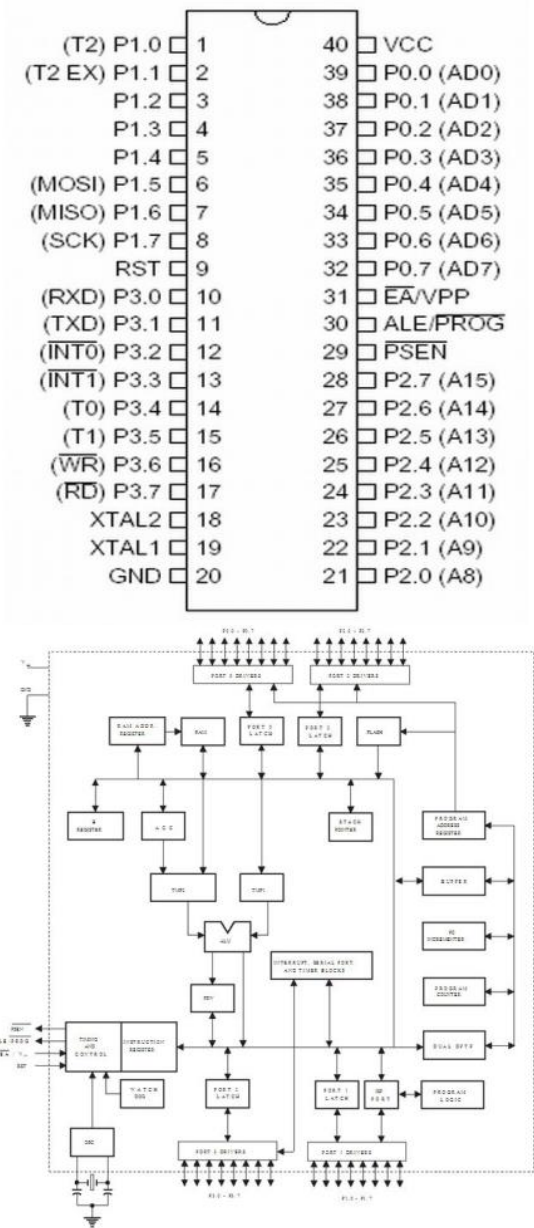

Gambar 7. Mikrokontroller AT89S52

Mikrokontroler AT89S52 merupakan IC yang memiliki $8 \mathrm{~Kb}$ flash PEROM (Programmable dan Erasable Read Only Memory) yaitu ROM yang dapat ditulis dan dihapus menggunakan perangkat programmer, memiliki $128 \times 8$ bit internal RAM 32. Programmable $1 / O$ lines dan keperluan port parallel. Satu port parallel terdiri dari 8 kaki dengan demikian 32 kaki tersebut membentuk 4 buah port parallel, yang masing-masing dikenal sebagai port0, port-1, port-2, dan port-3. Nomor dari masing-masing jalur/kaki dari port parallel 
mulai dari 0 sampai 7 , jalur/kaki pertama port-0 disebut sebagai P0.0 dan jalur / kaki terakhir untuk port-3 adalah P3.7. (Rachmad Setiawan, 2006).

\section{METODE PENELITIAN}

Pada penelitian ini menerapkan metode pengembangan perangkat keras dan perangkat lunak dari sistem pengaturan kecepatan motor universal. Adapun diagram blok rancangan penelitian ini diperlihatkan seperti pada gambar 8 . Prinsip kerja dari diagram blok di atas adalah zero crossing menghasilkan sinyal sinkronisasi dengan mendeteksi titik persilangan nol dari sumber tegangan bolak-balik. Sinyal sinkronisasi dikirim ke mikrokontroler AT89S52 digunakan sebagai titik start mengaktifkan waktu tunda penyalaan thyristor sehingga sudut fasa penyalaan thyristor selalu serempak dengan fasa sumber tegangan ac. Ketika waktu tunda sudut fasa penyalaan thyristor telah berakhir maka mikrokontroler membangkitkan pulsa penyulutan untuk thyristor. Pulsa penyulutan ini diperkuat terlebih dahulu oleh rangkaian driver sehingga mampu menghasilkan nilai arus penyulutan yang sesuai bagi thyristor agar bisa menghantarkan arus listrik. dari sumber tegangan ac ke motor universal. Dengan mengatur waktu tunda sudut penyalaan thyristor melalui keypad dapat diperoleh tegangan efektif yang bervariasi sehingga kecepatn motor universal akan ikut berubah.

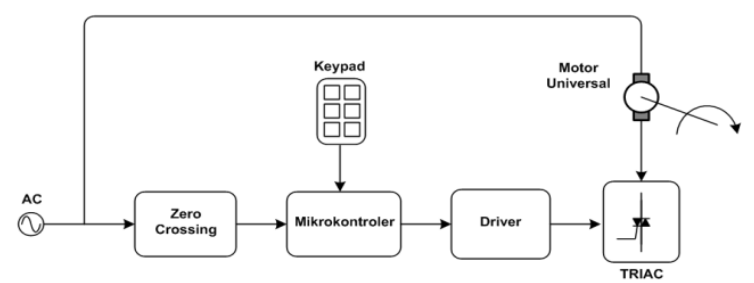

Gambar 8. Diagram blok sistem pengaturan kecepatan motor universal

Jantung utama dari pengaturan sudut fasa penyalaan thyristor ada pada mikrokontroler AT89S52. Tugas mikrokontroler adalah menghasilkan sinyal pulsa penyalaan thyristor sesuai dengan waktu tunda sudut penyalaan sejak menerima sinyal sinkronisasi dari rangkaian zero crsossing. Algoritma yang digunakan untuk menghasilkan fungsi mikrokontroler seperti tersebut diperlihatkan pada gambar 9.

Berdasarkan algoritma pada gambar 9 tersebut dapat dijelaskan prinsip kerjanya sebagai berikut: pertama kali mikrokontroler AT89S52 akan melakukan inisialisasi terhadap register misalnya menyetel nilai sudut fasa penyulutan yang diinginkan. Kemudian mikrokontroler melakukan pendeteksian sinyal sinkronisasi dari sumber tegangan ac. Jika ada sinyal sinkronisasi, maka waktu tunda penyalaan akan mulai diaktifkan yang lamanya sesuai dengan nilai yang sudah disetel pada register. Jika waktunya sudah habis maka mikrokontroler akan mengaktifkan pulsa triger dan selanjutnya dikirim ke thyristor.

Dalam penelitian ini rancangan sistem pengaturan kecepatan motor universal berbasis mikrokontroler AT89S52 akan diuji dalam beberapa variabel pengujian yakni pengujian sinyal sinkronisasi, pengujian respon sudut penyulutan terhadap sinyal sinkronisasi, dan pengujian linieritas tegangan keluaran efektif terhadap sudut penyalutan thyristor.

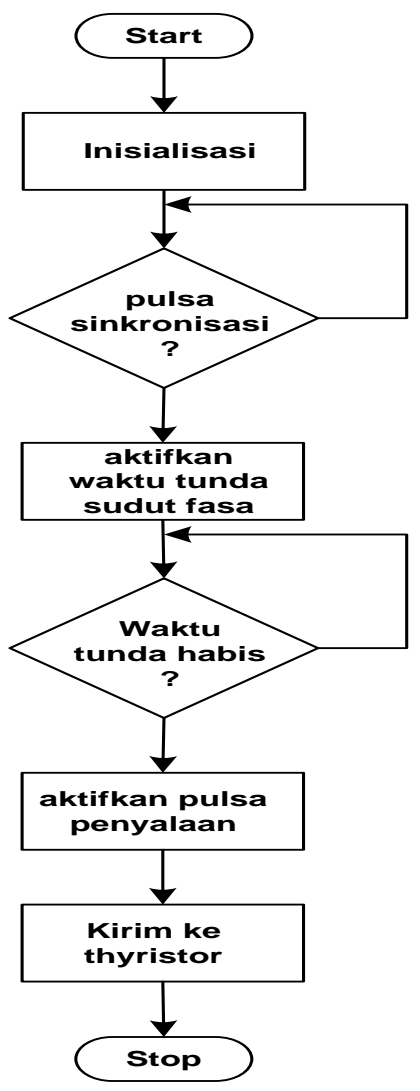


Gambar 9. Algoritma pengaturan sudut fasa penyulutan thyristor

\section{HASIL DAN PEMBAHASAN}

Berdasarkan pada rancangan diagram blok diperoleh hasil berupa rangkaian perangkat keras sistem pengaturan kecepatan motor universal berbasis mikrokontroler AT89S52 seperti tampak pada gambar 10 . Pada gambar tersebut zero crossing dibentuk oleh komponen transistor C 9012 berikut komponen pendukungnya. Transistor ini akan bekerja menghasilkan sinyal logika rendah pada terminal emitor jika tegangan sumber ac berada di bawah nilai tegangan referensi $5 \mathrm{~V}$. Sinyal pulsa sinkronisasi ini diserahkan ke mikrokontroller AT89S52 melalui terminal port P0.0. Kemudian mikrokontroler akan melakukan proses pengolahan waktu tunda sesuai dengan nilai yang diterima melalui penekanan tombol Up dan tombol Down. Kedua tombol ini mengatur lamanya sudut fasa penyulutan thyristor. Jika tombol Up ditekan maka nilai sudut fase akan mengecil dan thyristor akan disulut lebih cepat sehingga tegangan keluaran akan meningkat. Sebaliknya jika tombol down ditekan maka nilai sudut fasa akan membesar dan thyristor akan disulut lebih lambat sehingga tegangan keluaran efektif akan mengecil. Setelah sudut penyalaan berakhir maka mikrokontroler AT89S52 akan mengeluarkan sinyal trigger melalui port P2.0 sehingga thyristor (triac) dapat menghantarkan arus dari sumber ke beban motor universal.

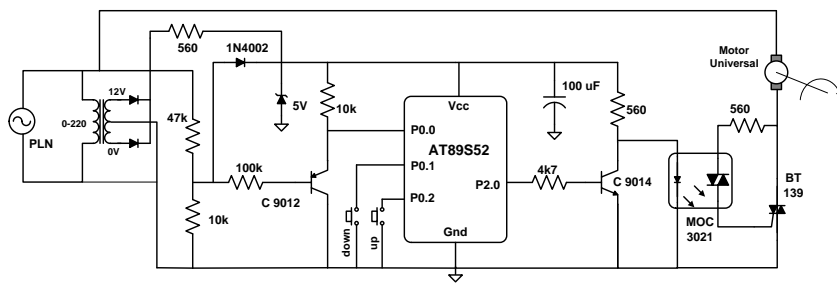

Gambar 10. Rangkaian sistem pengaturan kecepatan motor universal

Berdasarkan pengujian perangkat hardware dan software pada sistem pengaturan kecepatan motor universal 1 fasa berbasis mikrokontroler AT89S52 diperoleh hasil pengujian pertama berupa sinyal keluaran dari rangkaian zero crossing seperti tampak pada gambar 11 . Terlihat bahwa sinyal sinkronisasi berupa pulsa logika rendah (OV) yang muncul setiap kali sumber tegangan ac melewati titik persilangan nol. Periode sinyal sinkronisasi nilainya sebesar setengah dari periode gelombang sinus dari sumber tegangan ac. Karena frekuensi dari sumber tegangan ac PLN sebesar $50 \mathrm{~Hz}$ maka periode gelombang adalah $1 / 50 \mathrm{~Hz}$ atau 20 mili detik. Dengan demikian periode pulsa sinkronisasi sebesar 10 mili detik. Dalam periode tersebut diperoleh rentang sudut pengaturan dari sudut nol derajat sampai dengan sudut 180 derajat.

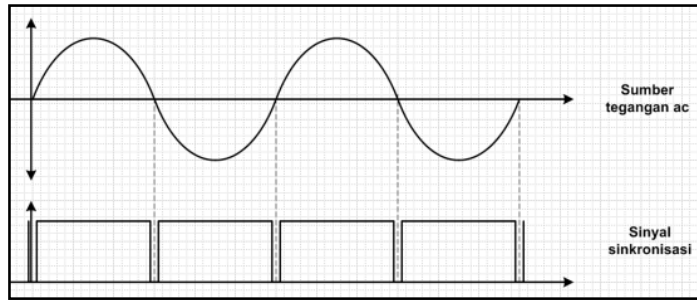

Gambar 11. Keluaran Zero Crossing terhadap Sumber Tegangan AC

Pada gambar 11, pulsa sinyal sinkronisasi berupa logika rendah dimana salah satu dari kedua sisi pulsa tersebut tidak tepat jatuh berada di titik persilangan nol. Hal ini disebabkan karena transistor dalam rangkaian zero crossing mulai dapat menghantar hanya jika tegangan sumber tegangan ac melebihi tegangan bias maju dioda basis-emitornya sebesar 0,7 Volt. Jadi di bawah nilai tersebut transistor akan tidak menghantar sehingga menghasilkan pulsa logika 0. Oleh karena itu, sisi naik dari pulsa sinkronisasi selanjutnya digunakan sebagai pulsa start untuk mengaktifkan pewaktuan sudut penyalaan thyristor . 


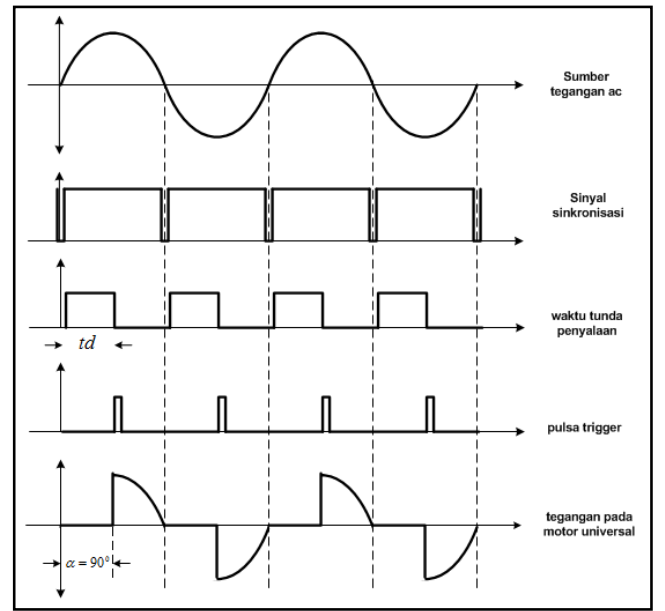

Gambar 12. Bentuk tegangan keluaran

motor universal terhadap sudut fasa

Pada gambar 12 memperilhatkan hasil pengujian yang kedua berupa respon mikrokontroler AT89S52 terhadap sinyal sinkronisasi dalam menghasilkan waktu tunda sudut fasa penyalaan thyristor. Terlihat bahwa waktu tunda penyalaan thyristor mulai diaktifkan hanya jika menerima pulsa positip dari sinyal sinkronisasi, dan selanjutnya waktu tunda berjalan sampai pada batas nilai yang telah ditentukan. Ketika waktunya sudah habis maka saat yang bersamaan muncul pulsa trigger dengan waktu yang sangat singkat. Pulsa trigger inilah yang menentukan penyalaan bagi thyristor sehingga diperoleh bentuk tegangan keluaran motor universal dengan belahan gelombang yang terpotong. Dari gambar tersebut jelaslah bahwa waktu tunda penyalaan menentukan posisi dari pulsa trigger yang juga menentukan sudut fasa penyalaan thyristor.

$$
\text { Pada gambar tersebut }
$$
memperlihatkan salah satu hasil pengukuran dengan nilai sudut penyulutan thyristor pada sudut fasa $90^{\circ}$. Terlihat bahwa pada rentang sudut di bawah $90^{\circ} \mathrm{di}$ mana belum terjadi pulsa penyulutan pada thyristor sehingga tidak muncul tegangan sumber ac pada beban motor universal. Kemudian setelah mencapai tepat $90^{\circ}$ di mana terjadi pulsa trigger dan menyulut thyristor sehingga muncul tegangan sumber ac tepat mulai dari sudut $90^{\circ}$ sampai sudut $180^{\circ}$ pada beban motor universal. Penyulutan thyristor terjadi pada belahan positip dan negatip dari sumber tegangan dengan sudut penyulutan yang tetap terhadap pulsa sinkronisasi.

Hasil pengujian yang ketiga yakni tegangan keluaran efektif pada motor universal berdasarkan sudut penyalaan thyristor. Hasil pengukuran tegangan efektif pada beban motor universal dengan variasi pengaturan sudut fasa seperti tampak pada tabel 1.

Tabel 1. Tegangan Motor Universal terhadap Sudut Penyalaan

\begin{tabular}{ccc}
\hline $\begin{array}{c}\text { Sudut } \\
\text { Penyalaan } \\
\text { (derajat) }\end{array}$ & $\begin{array}{c}\text { Waktu } \\
\text { Tunda } \\
\text { (mili detik) }\end{array}$ & $\begin{array}{c}\text { Tegangan } \\
\text { Motor } \\
\text { Universal } \\
\text { (Volt) }\end{array}$ \\
\hline 0 & 0 & 220 \\
\hline 10 & 0,55 & 219 \\
\hline 20 & 1,10 & 219 \\
\hline 30 & 1,65 & 217 \\
\hline 40 & 2,20 & 212 \\
\hline 50 & 2,75 & 206 \\
\hline 60 & 3,30 & 197 \\
\hline 70 & 3,85 & 185 \\
\hline 80 & 4,40 & 171 \\
\hline 90 & 4,95 & 155 \\
\hline 100 & 5,50 & 137 \\
\hline 110 & 6.05 & 117 \\
\hline 120 & 6,60 & 97 \\
\hline 130 & 7,15 & 75 \\
\hline 140 & 7,70 & 56 \\
\hline 150 & 8,25 & 37 \\
\hline 160 & 8,80 & 20 \\
\hline 170 & 9,35 & 5,6 \\
\hline 180 & 9,90 & 0 \\
\hline
\end{tabular}

Pada tabel tersebut terlihat bahwa tegangan keluaran efektif dari thyristor menuju beban motor universal semakin menurun seiring dengan peningkatan sudut fasa penyalaan. Hasil pengujian tersebut telah membuktikan hubungan antara tegangan keluaran efektif terhadap sudut penyalaan sesuai dengan persamaan di bawah ini.

$$
V o=\sqrt[2]{\frac{V m^{2}}{2 \pi}\left(\pi-\alpha+\frac{1}{2} \sin 2 \alpha\right)}
$$


Berdasarkan hasil pengukuran tegangan efektif pada beban motor universal seperti tabel di atas maka dapat diperoleh grafik hubungan antara tegangan beban terhadap variasi sudut penyalaan thyristor seperti tampak pada gambar 13 .

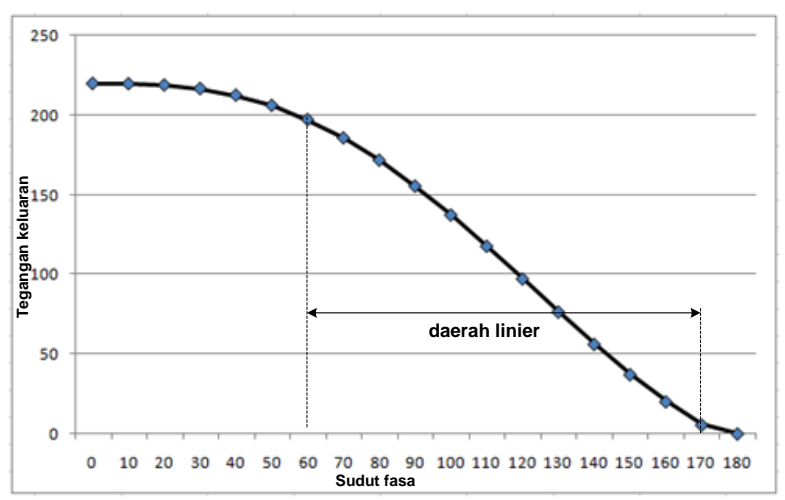

Gambar 13. Linieritas tegangan keluaran terhadap sudut fasa

Tampak pada grafik di atas bahwa pada setiap nilai sudut penyalaan thyristor memberikan nilai tegangan keluaran efektif yang berbeda pada motor universal. Pengaturan sudut fasa secara linier dengan pertambahan sudut dengan nilai tetap sebesar 10 derajat ternyata tidak menghasilkan respon tegangan keluaran efektif yang linier secara keseluruhan. Terlihat pada grafik dimana linieritas hanya terjadi mulai sudut 60 derajat sampai 170 derajat. Pada rentang sudut tersebut dimana perubahan tegangan keluaran efektif akan memberikan perubahan yang nyata pada kecepatan motor universal. Sedangkan pada sudut penyalaan antara 0 derajat hingga 60 derajat menghasilkan bentuk kurva tak linier sehingga hanya terjadi perubahan kecil pada tegangan keluaran dan juga kecepatan pada motor universal. Ketidaklinieran dari tegangan keluaran efektif terhadap pengaturan sudut fasa disebabkan karena tegangan keluaran tersebut merupakan fungsi akar kuadrat dari nilai sudut fasa sehingga tidak memiliki konstanta pembanding yang tetap.

Kecepatan motor universal dipengaruhi oleh tegangan keluaran efektif Vo seperti tampak pada persamaan berikut :

$$
n=\frac{E a}{c . \Phi}=\frac{V o-I a(R s+j X s)}{c . \Phi}
$$

Pada saat motor universal berputar mengalir arus jangkar la pada kumparan rotor dan stator. Arus jangkar tersebut juga membangkitkan fluks medan magnet $\Phi$ sehingga hubungan antara fluks magnet sebanding dengan arus jangkar atau dinyatakan dengan persamaan : $\Phi=k$ la. Jika persamaan fluks magnet disubsitusikan ke persamaan kecepatan motor universal di atas diperoleh hasil :

$$
n=\frac{V o}{k \cdot I a}-(R s+j X s)
$$

dan jika tegangan keluaran efektif terhadap sudut penyalaan thyristor disubstitusikan diperoleh persamaan :

$$
n=\frac{\sqrt[2]{\frac{V m^{2}}{2 \pi}\left(\pi-\alpha+\frac{1}{2} \sin 2 \alpha\right)}}{k \cdot I a}+(R s
$$

dari persamaan ini terbukti bahwa kecepatan motor universal juga sepenuhnya tidak akan linier dan mengikuti nilai dari akar kuadrat sudut fasa penyalaan thyristor. Karena adanya perlawanan dari reaktansi kumparan jangkar dan stator Rs + jXs yang nilainya selalu tetap maka bentuk kecepatan motor universal tidak akan jauh berbeda dengan bentuk kurva di atas.

\section{SIMPULAN DAN SARAN}

Berdasarkan hasil dan pembahasan di atas maka dalam penelitian ini dapat diperoleh kesimpulan sebagai berikut :

1. Pengembangan perangkat keras dan lunak dalam pengaturan kecepatan motor universal dengan metode kontrol sudut fasa penyalaan thyristor berbasis mikrokontroler AT89S52 telah bekerja dengan baik dalam rentang pengaturan sudut fasa dari nol derajat sampai 180 derajat.

2. Linieritas pengaturan sudut fasa penyalaan thyristor dalam rentang sudut pengaturan dari nol derajat sampai 180 derajat tidak diimbangi dengan linieritas kecepatan motor universal karena merupakan fungsi dari akar kuadrat sudut fasa.

\section{Saran-Saran}

Perlu diterapkan metode yang lain dalam pengaturan tegangan keluaran 
efektif sehingga diperoleh linieritas pengaturan tegangan pada motor universal. Pengaturan kecepatan motor universal dalam penelitian ini belum menerapkan kendali dengan umpan balik sehingga masih tergolong kontrol loop terbuka. Oleh karenanya kecepatan motor masih dipengaruhi oleh perubahan beban. Dalam pengembangan berikutnya perlu dilanjutkan dengan menerapkan kendali umpan balik sehingga kecepatannya dapat dipertahankan konstan tanpa dipengaruhi oleh pembebanan.

\section{DAFTAR PUSTAKA}

Rachmad Setiawan, 2006, Mikrokontroller MCS-51, Penerbit Graha IImu, Yogyakarta.

JM. Bourgeois dkk, 1994, Improved Universal Motor Drive, http://www.st.com/st-webui/static/active/jp/resource/technical/ document/ application_note/CD00003829.pdf

Robert W. Erickson, 2001, Fundamentals of Power Electronics, Kluwer Academic Publishers, New York

ON Semiconduktor, 2007, TDA 1085 Universal Motor Speed Controller, http://www.onsemi.com/pub_link/Col lateral/TDA1085C-D.PDF

Motor Universal, http://id.wikipedia.org/wiki/Motor_uni versal, di download 25 Januari 2015 